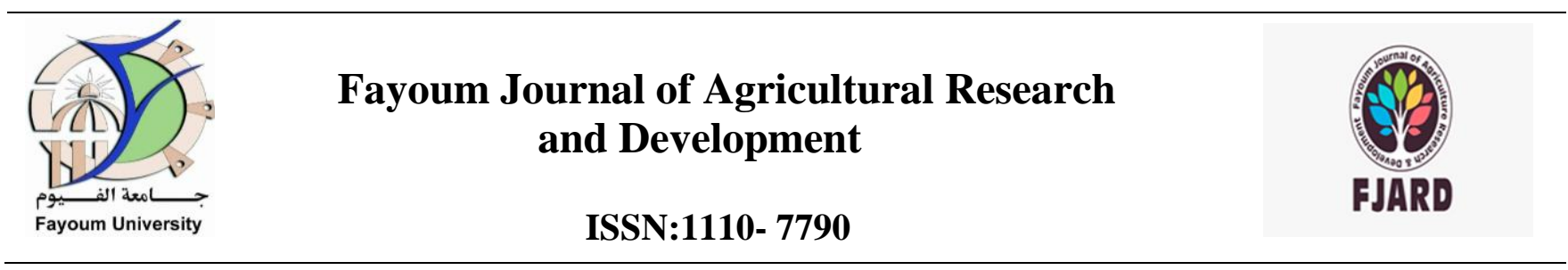

\title{
Purification and some properties of fungal Xylanase
}

\author{
Marwa, H. M'., Abou Al-kasem, N. ${ }^{2}$, Mansour, S. $\mathbf{M}^{1}$. and Abdelaliem, Y. F ${ }^{3}$. \\ ${ }^{1}$ Microbiology, Soil, Water and Environment Res. Institute, Agric, Res. Center, Giza, Egypt, \\ ${ }^{2}$ Botany Department, Faculty of Science, Fayoum University, Fayoum, 63514, Egypt \\ ${ }^{3}$ Microbiology Department, Faculty of Agriculture, Fayoum University, Fayoum,63514, \\ Egypt
}

\section{Abstract}

Partial purification of xylanase produced by Aspergillus niger strain AUMC 14230 is carried out with $80 \%$ saturation of ammonium sulfate under pH5.0 as first step. The second step in partial purification is Acetone 2.5/1 (v/v). The last step is gill filtrations which give the highest specific from both enzymes. Many factors affecting on purified enzymes. The best activity of xylanase was produced till $72 \mathrm{hrs}$ and decreased by $(8.8 \%$ \& $10.9 \%)$, respectively after $72 \mathrm{hrs}$. Xylan $(1 \mathrm{mg})$ concentration was the best substrate to produce relative activity $100 \%$ for xylanase enzyme. We found that the glucose has an inhibitory effect on both enzymes activity. Optimum temperature for xylanase is $50^{\circ} \mathrm{C}$, increased temperature decreased productivity of both enzymes. The addition of $\mathrm{Ca}^{2+}, \mathrm{Ba}^{2+} \mathrm{Mg}^{2+}$ and EDTA strongly enhanced both xylanase activity, While, $\mathrm{Co}^{2+}$ and $\mathrm{Ag}^{+}$decreased the productivity. On the other hand, the $\mathrm{Fe}^{2+}, \mathrm{Cu}^{2+}$ and $\mathrm{Mn}^{2+}$ showed moderate inhibition.

\section{KEYWORDS: Fungal Xylanase, agricultural and industrial wastes, Aspergillus niger strain}

\footnotetext{
* Corresponding author: Marwahamdy848@gmail.com

Received: 9/11/ 2020

Accepted: 23/12/ 2020
} 


\section{Introduction}

Xylan, the main component of hemicellulose consists of a $\beta-1,4-$ linked d-xylosyl residues backbone branched with other pentoses, hexoses and uronic acids. Xylanases and associated de branching enzymes produced by a variety of microorganisms, including bacteria, yeasts and filamentous fungi, bring about the hydrolysis of hemicelluloses (Gilbert and Hazlewood, 1993, Maheshwari et al., 2000 and Katapodis et al., 2000 and 2002). They also reported that Xylanase are also believed to be essential in improving the nutritive quality of animal feed. The abundance of xylan clearly indicates that xylanolytic enzymes can play an important role in bioconversion. Furthermore, it may also be possible to use xylanases in bio pulping processes for the preparation of cellulose pulps. Xylan is the major hemicellulose in hardwood from angiosperms, but is less abundant in softwood from gymnosperms; it accounts for approximately 15\%-30\% and $7 \%-12 \%$ of the total dry weight, respectively (Whistler and Richards 1970; and Beg et al., 2001). Applications of xylanases can be found in the food, feed and pulp-paper industry. Filamentous fungi are particularly interesting producers of this enzyme from an industrial point of view, due to the fact that they excrete xylanases into the medium. Furthermore, xylanase levels from fungal cultures are generally much higher than those from yeasts or bacteria. In addition to xylanase, fungi typically produce several accessory xylanolytic enzymes, which are necessary for debranching substituted xylans ( Haltrich etal.,1996).
The present study reports the purification of extracellular xylanase from Aspergillus niger strain AUMC 14230. Earlier we have reported the factors affecting on purified enzyme.

\section{Materials and Methods}

Fungi used

Strains isolated from corn cob collected from Egypt corn field in 2018 and also isolated from water, soil and air. This cultures were maintained on potato dextrose agar slants and held at $4^{\circ} \mathrm{C}$ and were renewed monthly.

\section{Culture condition}

Aspergillus niger was cultured on modified medium (Corn steep liquor (3\%), Corn cob (1\%) and Wheat bran $(1 \%)$. The $\mathrm{pH}$ of the medium was adjusted to 4.5 befor autoclaving. Inoculum size $0.50 \%(\mathrm{v} / \mathrm{ml})$, initial $\mathrm{pH}$ 4.5, aeration $1: 5(\mathrm{Vm}: \mathrm{Vf})$, incubation temperature $50^{\circ} \mathrm{C}$, agitation rate 175 rpm and time course $72 \mathrm{hr}$ and the supernatant assayed for enzymatic activities.

\section{Enzyme assay}

Xylanase activity was assayed by measuring the reducing sugars released from birchwood xylan. The reaction mixture containing $0.5 \mathrm{ml}$ enzyme solution and $0.5 \mathrm{ml}$ of xylan solution $1 \%(\mathrm{w} / \mathrm{v})$, in $0.05 \mathrm{M}$ acetate buffer $(\mathrm{pH}$ 5.0) was incubated at $50^{\circ} \mathrm{C}$ for $30 \mathrm{~min}$. The reducing sugars released were determined as xylose by the method of Somogyi (1952). One unit (U) of xylanase activity was defined as the amount of enzyme that produced $1 \mathrm{~m}$ mole of xylose per min under assay conditions.

\section{Enzyme purification}

The xylanase was purified using three different methods:

\section{By using ammonium sulfate}

To the enzyme culture filtrate $(12.5 \mathrm{ml})$ at different $\mathrm{pH}$ values, solid ammonium sulfate was added up to $80 \%$ saturation $(\mathrm{S})$. The mixture was 
Marwa, H. M., et al.

left over night at $4^{\circ} \mathrm{C}$ and the precipitate was collected by centrifugation at $15,000 \mathrm{rpm}$ for 30 min in a cooling centrifuge. The experiment was repeated using ammonium sulfate at different saturations being 10\%, 20\%, 30\%, $40 \%, 50 \%, 60 \%, 70 \%, \& 80 \%$, (S).The precipitate was dissolved in $10 \mathrm{ml}$ of acetate buffer $\mathrm{pH} 4.5$ then the enzyme activity and protein concentration were determined.

\section{By organic solvents}

This experiment was conducted to find out the most suitable solvent for the highest recovery of enzyme. Acetone, ethanol and isopropanol 1/1, 1.5/1,2/1, 2.5/1, 3/1,3.5/1 and4/1 V/V were used for the precipitation of enzyme culture filtrate. Solvents, precooled to $20 \mathrm{oC}$ were added slowly (Mill and Tuttobello, 1961).

3.By gel filtration

The dialyzed sample was separated on non-denaturing electrophoresis slab gel (12\% polyacrylamide) containing $10 \%$ sucrose. After electrophoresis the slab gel was laid on the agar sheet containing $0.5 \%(\mathrm{w} / \mathrm{v})$ xylan and $20 \%$ (w/v) $\mathrm{NaCl}$ in above mentioned buffer as replica plate and left for $2 \mathrm{~h}$ at 50 ${ }^{\circ} \mathrm{C}$, the agar overlay was removed and stained with $0.2 \%(\mathrm{w} / \mathrm{v})$ aqueous. Sodium dodecyl sulphate polyacrylamide gel electrophoresis (SDS-PAGE) was carried out on a $12 \%$ polyacrylamide gel. After electrophoresis, the protein gel was stained with Coomassie Brilliant Blue R-250 (Prakash et al., 2012).

Determination of soluble protein

Protein in these experiments was determined by the method of Lowry $\boldsymbol{e t}$ al. (1951) using bovine serum albumin as standard.

Effect of pH on the rate of catalyzed reaction

\section{Optimum pH}

FJARD VOL. 35, NO. 1. PP. 41-56 (2021)

Therefor the effect of substrate was estimated by using suffiently high concentration of substrate the enzyme at all $\mathrm{pH}$ used. The effect of $\mathrm{pH}$ on the activity of the partial purified xylanase of Aspergillus niger strain AUMC 14230 was studied in various buffers over the $\mathrm{pH}$ ranges of $(3.0-8.0)$. The buffer used was citrate buffer (3.0-6.0), and phosphate buffer (7.0-8.0).

\section{2. pH stability}

The $\mathrm{pH}$ value was adjusted to various levels between 3.0 to 8.0 using citrate phosphate buffer (3.0-7.0) and phosphate buffer (7.0-8.0) and adjustment by $\mathrm{pH}$ meter. All solution in the flasks adjusted to the desired $\mathrm{pH}$ were left at $4^{\circ} \mathrm{C}$ for one or five days. The $\mathrm{pH}$ stability was investigated by measuring the residual activity on xylanase at $50^{\circ} \mathrm{C} \mathrm{pH} 5.0$ for $10 \mathrm{~min}$ after $24 \mathrm{~h}$ or $120 \mathrm{~h}$ incubation at the same range of $\mathrm{pH}$ as before.

\section{Effect of substrate concentration}

To study the effect of substrate concentrations on the velocity of the partial purified xylanase from Aspergillus niger strain AUMC 14230 the following experiment was run. The concentration of xylan varied from 0.03 to $0.45 \mathrm{mM}$. The mixture was incubated for $10 \mathrm{~min}$ at $50^{\circ} \mathrm{C}$ and $\mathrm{pH}$ 5.0, while the concentration of cellobiose varied from 0.1 to $1.0 \mathrm{mM}$.

\section{Substrate specificity}

One $\mathrm{ml}$ of enzyme solution was incubated with $1 \mathrm{ml}$ of each substrate in citrate-phosohate buffer $(0.05 \mathrm{M}, \mathrm{pH}$ 5.0) at the optimum temperature of each enzyme. The sugars obtained from carboxy methyl cellulose (CMC), xylan, filter paper, cellulose, Salicin, treated and untreated rice straw were determined (as glucose) by the method of Smogyi, (1952). The glucose released from lactose, maltose and xylose determined by glucose-oxidase reagent. 


\section{Glucose inhibition}

The inhibition of glucose on enzyme activity was measured by adding various concentrations of glucose (10 to $100 \mathrm{mM}$ ) and xylan concentration with $(0.1,0.2,0.3$ to $1.0 \mathrm{mM})$. Inhibition study by glucose was performed with xylan as the substrates.

\section{Effect of temperature}

\section{Optimum temperature}

In each experiment $0.5 \mathrm{ml}$ of xylanase were added to $0.5 \mathrm{ml}$ of sodium acetate and the reaction continued for 30 minutes. The experiment was then conducted at different temperature i.e. $20,25,30,35,40,45,50,55,60,65$, 70 and $75^{\circ} \mathrm{C}$. The reaction velocity was determined and the optimum temperature was calculated by plotting enzyme activates against temperatures.

\section{Thermal stability}

An experiment was designed to study the effect of different temperatures and times stability of xylanase. The enzyme incubated at nine various temperatures ranged from $30^{\circ} \mathrm{C}$ to $70^{\circ} \mathrm{C}$ with $5^{\circ} \mathrm{C}$ intervals. Samples were taken for potency determination at various times being 10, 20, 30, 40, 50, and $60 \mathrm{~min}$, the residual activities in each case was determined and calculated as relative activity.

\section{Effect of metal ion and some}

\section{substances on cellobiase activity}

The effect of metal ions and some substances on reaction velocity catalyzed by cellobiase was determined using $\mathrm{Na}^{+}, \mathrm{K}^{+}, \mathrm{Co}^{+2}, \mathrm{Ca}^{+2}$, $\mathrm{Mg}^{+2}, \mathrm{Mn}^{+2}, \quad \mathrm{Cu}^{+2}, \mathrm{Zn}^{+2}, \mathrm{Ag}^{+}$and EDTA. All factors were kept constant then the xylanase activity was determined as affected by addition of metal ions and some substances.

Results and discussion

1. Purification studies

1.1. Effect of ammonium sulfate concentration
The results presented in Table (1) revealed that the xylanase activity by Aspergillus niger was started with low values when the low ammonium sulfate concentration were used (10, 20 , and $30 \%$ ). Then it increased as the ammonium sulfate increased to reach its maximum values $\left(2000 \mathrm{Uml}^{-1}\right)$ at the high concentrations of ammonium sulfate (80, 90 and 100\%) which gave the same xylanase activity. The same trend was found for protein where the high concentration of ammonium sulfate $(80,90$ and $100 \%)$ gave the highest protein found in precipitation $\left(14 \mathrm{mgml}^{-1}\right)$. The most employed salt is ammonium sulfate, on account of its large solubility in water and absence of harmful effects on most enzymes (Englard and Seifter, 1990). Isolation of xylanase from Aspergillus niger was carried out by different types of chromatography (Prakash et al., 2012). It has in fact a stabilizing action on many enzymes and it is usually not necessary to carry out the fractionations at a low temperature. Therefore, the experiments were carried out to study the effect of some factors on enzyme precipitation using ammonium sulfate. The filtrates were filtered through paper and concentrated using evaporator under vacuum equipped (Chapla et al., 2012). In this connection Walia et al., (2017) reported that crude xylanase preparation was subjected to ammonium sulfate fractional precipitation and caused substantial concentration of proteins. The activity could be recovered from the ammonium sulfate fractional range of $30-80 \%$ with maximum at $60-80 \%$. There were sufficient reports regarding the inclusion of ammonium sulfate fractionation in the purification procedures. The specific activity of the concentrated preparation was 10.75 
Marwa, H. M., et al.

$\mathrm{U} / \mathrm{mg}$ proteins with a purification fold of 1.21 and the yield as $71.43 \%$.

\section{Effect of organic solvents}

The obtained results in Table (2 and 3) indicate that using the organic solvents in the precipitation of xylanase considered a very important step in partial purification of both enzymes. Using acetone in the concentration of 2 $/ 1 \mathrm{ml}$ (crude enzyme) gave the highest values of enzyme activity, S. activity, degree of purification and E.recovery.
FJARD VOL. 35, NO. 1. PP. 41-56 (2021)

Whereas, using ethanol at a concentration of 2/1 gave the maximum enzymes activity, $\mathrm{S}$. activity, degree of purification and $\mathrm{E}$. recovery. On the other hand, isopropanol 2/1 was highest in enzyme activity, protein concentration, $S$. activity, E. recovery and degree of purification. In our study we preferred to use acetone because of its strong hydration effect.

Table (1) Effect of ammonium sulfate concentration on xylanase enzyme precipitation from Aspergillus niger strain AUMC 14230.

\begin{tabular}{|c|c|c|c|c|c|c|}
\hline \multicolumn{2}{|c|}{$\begin{array}{c}\text { Ammonium } \\
\text { sulfate S \% } \\
\text { saturation }\end{array}$} & $\begin{array}{c}\text { Protein } \\
\text { mg mL }^{-1}\end{array}$ & $\begin{array}{c}\text { Activity } \\
\text { UmL }^{-1}\end{array}$ & $\begin{array}{c}\text { Specific } \\
\text { activity } \\
\text { Umg }\end{array}$ & $\begin{array}{c}\text { Degree } \\
\text { purification } \\
\text { fold }\end{array}$ & $\begin{array}{c}\text { Enzyme } \\
\text { recovery } \\
\%\end{array}$ \\
\hline \multicolumn{2}{|c|}{ Crude enzyme } & $\mathbf{3 4}$ & $\mathbf{2 0 5 0}$ & $\mathbf{6 0}$ & $\mathbf{0 . 0}$ & $\mathbf{1 0 0}$ \\
\hline $\mathbf{1 0}$ & $\mathbf{0 . 1 3}$ & 5 & 25 & 5 & 0.08 & 1 \\
\hline $\mathbf{2 0}$ & $\mathbf{0 . 2 6}$ & 7 & 265 & 37 & 0.61 & 12 \\
\hline $\mathbf{3 0}$ & $\mathbf{0 . 3 9}$ & 8 & 450 & 56 & 0.93 & 21 \\
\hline $\mathbf{4 0}$ & $\mathbf{0 . 5 2}$ & 9 & 705 & 78 & 1.31 & 34 \\
\hline $\mathbf{5 0}$ & $\mathbf{0 . 6 5}$ & 10 & 986 & 98 & 1.62 & 48 \\
\hline $\mathbf{6 0}$ & $\mathbf{0 . 7 8}$ & 11 & 1232 & 112 & 1.80 & 60 \\
\hline $\mathbf{7 0}$ & $\mathbf{0 . 9 1}$ & 12 & 1575 & 131 & 2.18 & 77 \\
\hline $\mathbf{8 0}$ & $\mathbf{1 . 0 4}$ & 14 & 2000 & 143 & 2.38 & 97 \\
\hline $\mathbf{9 0}$ & $\mathbf{1 . 1 6}$ & 14 & 2000 & 143 & 2.38 & 97 \\
\hline $\mathbf{1 0 0}$ & $\mathbf{1 . 2 8}$ & 14 & 2000 & 143 & 2.38 & 97 \\
\hline
\end{tabular}


Marwa, H. M., et al.

FJARD VOL. 35, NO. 1. PP. 41-56 (2021)

Table (2) Effect of organic solvents on xylanase precipitation from Aspergillus niger.

\begin{tabular}{|c|c|c|c|c|c|}
\hline $\begin{array}{c}\text { precipitation } \\
\mathbf{v} / \mathbf{v}\end{array}$ & $\begin{array}{l}\text { Activity } \\
\text { UmL-1 }\end{array}$ & \begin{tabular}{|c|} 
protein \\
Concentration \\
mg\%
\end{tabular} & $\begin{array}{l}\text { S.activity } \\
\text { (Umg-1 ) }\end{array}$ & $\begin{array}{c}\text { Degree of } \\
\text { purification }\end{array}$ & $\begin{array}{c}\text { E.recovery } \\
\%\end{array}$ \\
\hline Control & 3050 & 51 & 60 & 1 & 100 \\
\hline \multicolumn{6}{|c|}{ 1-Asetone } \\
\hline $1 / 1$ & 1674 & 17 & 98 & 1.60 & 55 \\
\hline $1.5 / 1$ & 2007 & 19 & 105 & 1.75 & 66 \\
\hline $2 / 1^{*}$ & 2442 & 20 & 122 & 2.00 & 80 \\
\hline $2.5 / 1$ & 2025 & 19 & 106 & 1.76 & 66 \\
\hline $3 / 1$ & 1905 & 18 & 105 & 175 & 62 \\
\hline $3.5 / 1$ & 1720 & 17 & 101 & 1.68 & 56 \\
\hline $4 / 1$ & 1503 & 15 & 100 & 1.66 & 49 \\
\hline \multicolumn{6}{|c|}{ 2-Ethanol } \\
\hline $1 / 1$ & 1470 & 17 & 86 & 1.4 & 48 \\
\hline $1.5 / 1$ & 1960 & 18 & 108 & 1.8 & 64 \\
\hline $2 / 1$ & 2266 & 19 & 119 & 1.9 & 74 \\
\hline $2.5 / 1 *$ & 2620 & 21 & 125 & 2.0 & 85 \\
\hline $3 / 1$ & 2150 & 20 & 107 & 1.7 & 70 \\
\hline $3.5 / 1$ & 1860 & 19 & 98 & 1.6 & 60 \\
\hline $4 / 1$ & 1360 & 18 & 75 & $\mathbf{1 . 3}$ & 44 \\
\hline \multicolumn{6}{|c|}{ 3-Isopropanol } \\
\hline $1 / 1$ & 1480 & 17 & 87 & 1.4 & 49 \\
\hline $1.5 / 1$ & 1806 & 19 & 95 & 1.6 & 59 \\
\hline $2 / 1^{*}$ & 2107 & 20 & 109 & 1.8 & 69 \\
\hline $2.5 / 1$ & 1966 & 19 & 103 & 1.7 & 64 \\
\hline $3 / 1$ & 1745 & 18 & 97 & 1.6 & 57 \\
\hline $3.5 / 1$ & 1500 & 16 & 94 & 1.5 & 49 \\
\hline $4 / 1$ & 1160 & 15 & 77 & 1.3 & 38 \\
\hline
\end{tabular}

Table (3) Summary of partial purification of xylanase secreted by A.niger.

\begin{tabular}{|c|c|c|c|c|c|}
\hline $\begin{array}{c}\text { Purification } \\
\text { steps }\end{array}$ & $\begin{array}{c}\text { Total activity } \\
\text { Uml -1 }\end{array}$ & $\begin{array}{c}\text { Total } \\
\text { protein } \\
\text { mg ml -1 }\end{array}$ & $\begin{array}{c}\text { Specific } \\
\text { activity } \\
\text { Umg } \\
\text { protein }\end{array}$ & $\begin{array}{c}\text { Purification } \\
\text { factor } \\
\text { (fold) }\end{array}$ & $\begin{array}{c}\text { Recovery } \\
\%\end{array}$ \\
\hline Crude extract & $\mathbf{2 6 5 0 0 0}$ & $\mathbf{6 7 5 5}$ & $\mathbf{3 9}$ & 1 & $\mathbf{1 0 0}$ \\
\hline $\begin{array}{c}\text { Ammonium } \\
\text { sulfate }\end{array}$ & $\mathbf{1 5 2 0 0 0}$ & $\mathbf{3 3 0}$ & $\mathbf{4 6 0}$ & $\mathbf{1 2}$ & $\mathbf{5 7}$ \\
\hline Acetone & $\mathbf{1 1 0 0 0 0}$ & $\mathbf{2 0 0}$ & $\mathbf{5 5 0}$ & $\mathbf{1 4}$ & $\mathbf{4 6}$ \\
\hline
\end{tabular}


Marwa, H. M., et al.

3. Electrophoresis of the SDS-PAGE It is clearly shown in Figure (1) that after migrated xylanase enzyme on SDS-PAGE there is 3 bands at 130, 52, and $6.5 \mathrm{Kda}$.

\section{Factors affecting partial purified enzyme reaction Optimum pH and pH stability}

Results in Figure (2 and 3) revealed that both enzyme activities and relative activity increased by increasing $\mathrm{pH}$ till it reached the highest level between 4.5 and 5.5 with $100 \%$ relative activity at 5.0. The results are in agreement with those obtained by Kaushik et al., (2014) who found that the enzyme was more stable at acidic $\mathrm{pH}$ ranges. Good stabilities were seen at the $\mathrm{pH}$ range of 4-7 even after $3 \mathrm{~h}$ of incubation.
FJARD VOL. 35, NO. 1. PP. 41-56 (2021)

Enzyme was most stable at $\mathrm{pH} 5$, retaining more than $98 \%$ activity even after $3 \mathrm{~h}$ of incubation. Even at $\mathrm{pH} 8$ and 9 , more than $85 \%$ and $75 \%$ enzyme stability, respectively, was observed after $3 \mathrm{~h}$ of incubation. Also, Das and Ray (2016) reported that the $\mathrm{pH}$ stability of the enzyme was studied at the $\mathrm{pH}$ range of 3.6 to 8.0 using 0.1 (M) acetate buffer for $\mathrm{pH} 3.6$ to 5.0 and $0.1(\mathrm{M})$ phosphate buffer for $\mathrm{pH}$ 5.4 to 8.0 . It was done by incubating the enzyme at this $\mathrm{pH}$ for $1 \mathrm{~h}$ at $30^{\circ} \mathrm{C}$ and then determining the residual xylanase activity under standard assay conditions. These results are similar to those obtained by (Chipeta et al., 2008, Bakri et al., 2011, Walia et al., 2015 and Bedade et al., 2017).
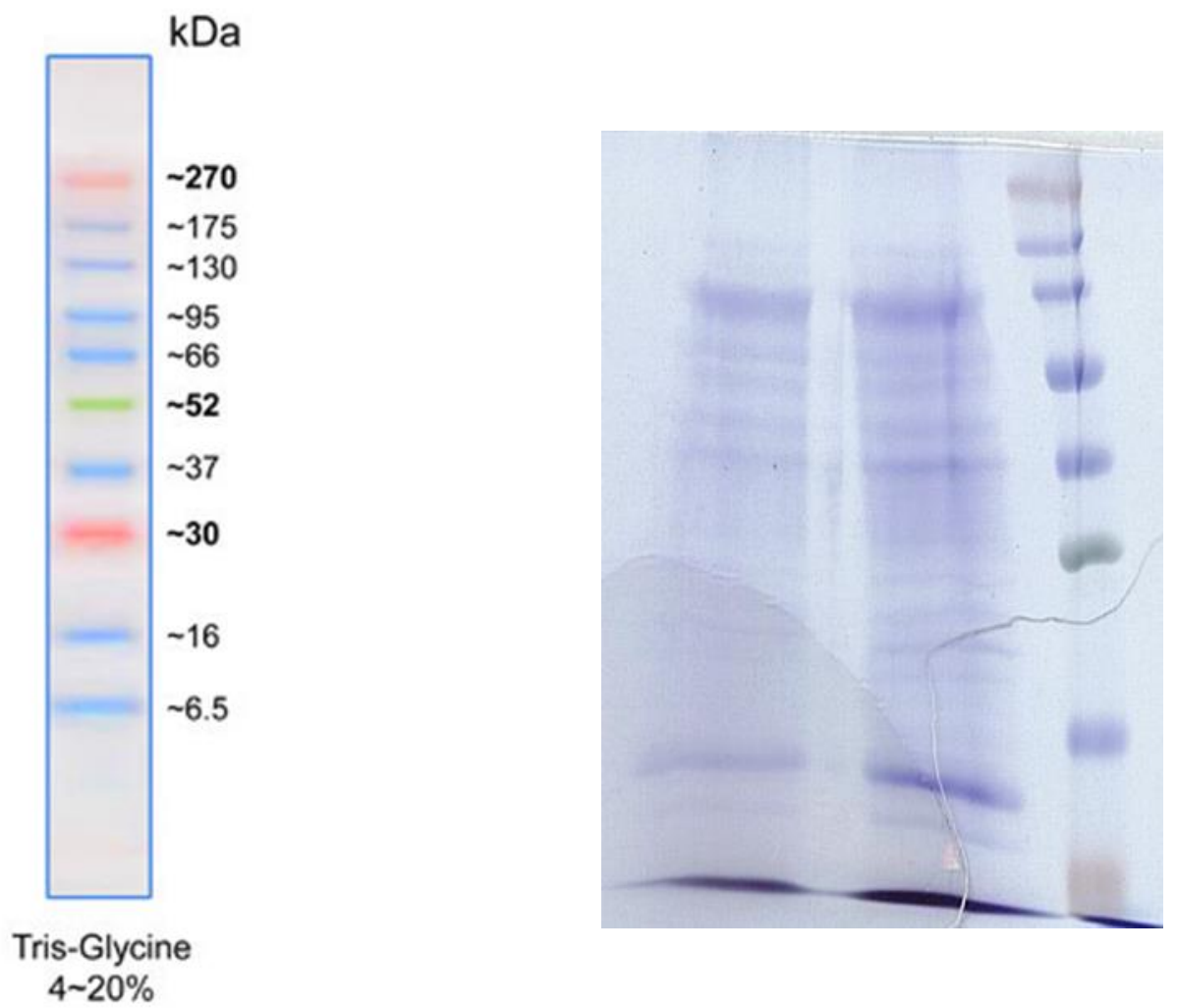

Figure (1)

GeneDireX BLUItra Prestained Protein Ladder (500ul) /PM001-0500 


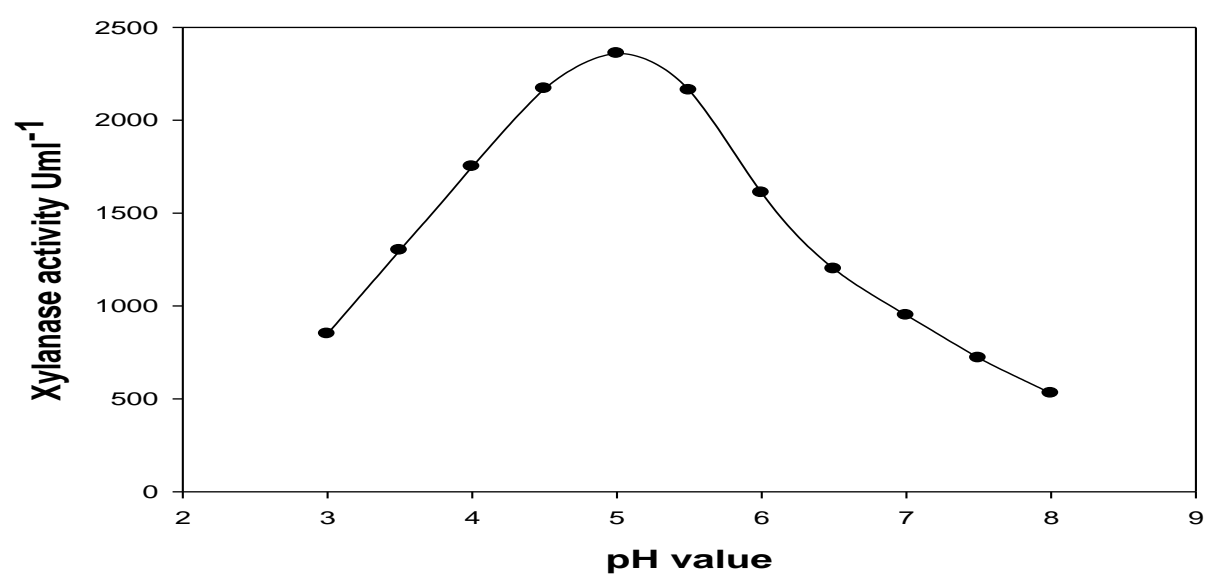

Figure (2) Effect of $\mathrm{pH}$ on the activity of partial purified xylanase from A.niger

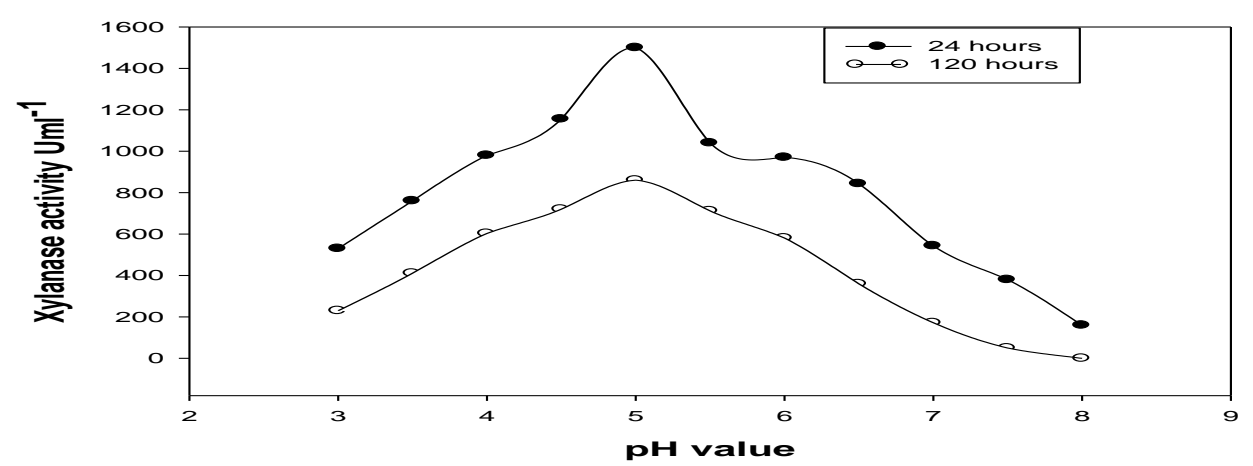

Figure (3) Effect of pH stability during storage of partial purified xylanase from A.niger.

\section{Effect of substrate specificity}

Among the substrate tested as shown in Figure (4) the xylan was the best substrate for the xylanase activity produced by $A$. niger followed by sucrose substrate. On the other hand, Ping et al., (2017) revealed that Tricoderma aurantiacus $M-2$ xylanase had high activity on xylan from beech wood and no activity on MCC, soluble starch, CMC-Na, 1,3 glucan and 1,6 glucan. These results were in harmony with those obtained by (Seyis and Aksoz, 2003, Singh et al., 2003, Simair et al., 2010, and, Das and Ray, 2016 and Bedade et al., 2017). Effect of substrate concentration The results recorded in Figure (5) recorded that for xylanase activity a concentration of 1.0 from xylan was the concentration for producing the higher activity of $\beta$-xylanase from the Aspergilus strain. The results may be attributed to the saturation of the enzyme obtained from substrate used and the enzymes showed affinity to the xylan. Also, purified xylanase had a narrow substrate specifity and could hydrolyze only xylan. Our results are in the same trend with those reported by (Bailey et al., 1992, Khanna and Gauri 1993, Puchart et al., 1999, Adsul et al., 2004, Okafor et al., 2007, Juturu and Wu, 2012, Prakash et al., 2012, Kaushik et al., 2014, Thomas et al., 2015 and Ping et al., 2017). 


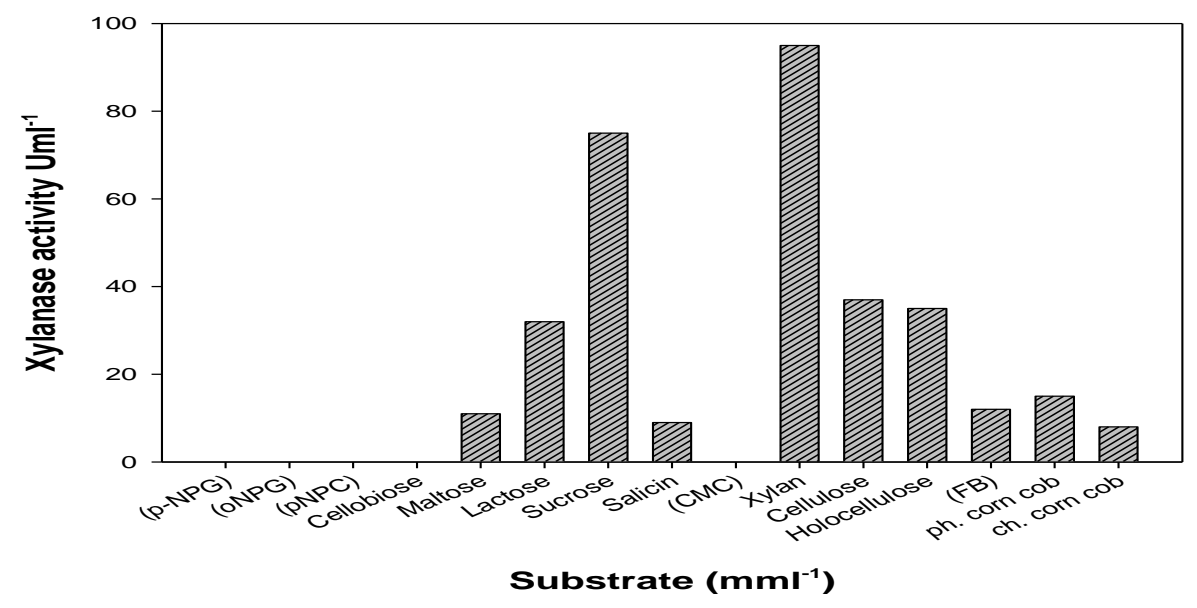

Figure (4) Substrate specificity of partial purified extracellular xylanase from A.niger

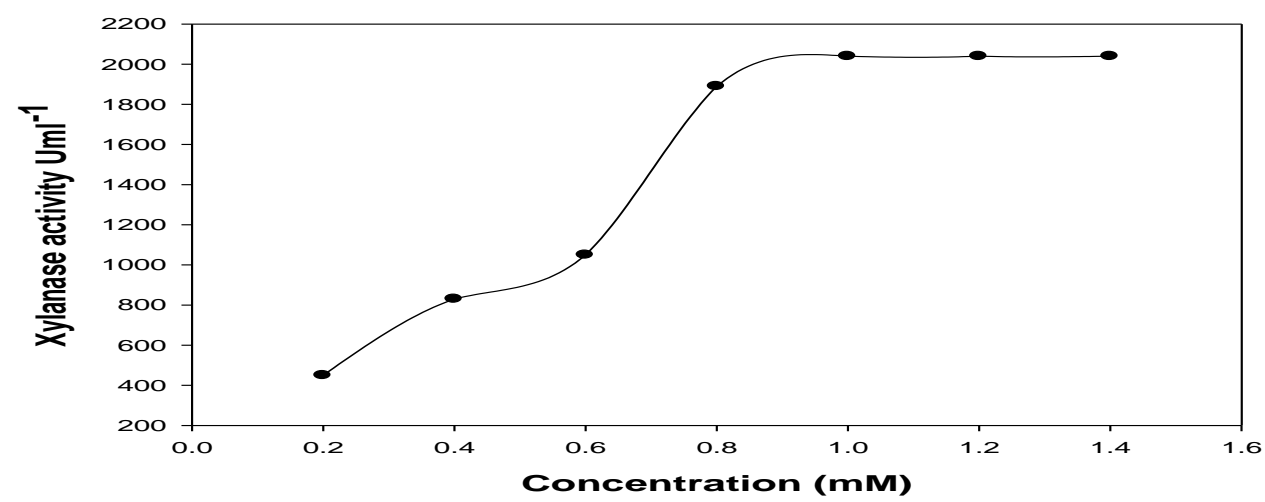

Figure (5) Effect of substrate concentration on partial purified xylanase activity of A.niger.

Thermodynamic of enzyme catalyze reaction

\section{Optimum temperature}

Results presents in Figure (6) revealed that the optimal temperature for thermodynamic of $A$. niger enzyme catalyzer reaction in this study was found to be $50^{\circ} \mathrm{C}$ then decreased at $70^{\circ} \mathrm{C}$ to be inactivated at 75 and $80^{\circ} \mathrm{C}$. These results may be attributed to that after $50^{\circ} \mathrm{C}$ the enzymes are subjected to denaturation. Similar results were also obtained by (Prakash et al., 2012, Sarkar et al., 2013, Pirota et al., 2013 and Kaushik et al., 2014). 2.Thermal stability of xylanase production from A. niger.
Results recorded in Figure (7) showed that the thermal stability of xylanase enzyme from A.niger was $50^{\circ} \mathrm{C}$ with relative activity $100 \%$ after $10 \mathrm{~min}$, whereas, increasing the time to 20,30 , 40,50 and $60 \mathrm{~min}$ gradually decreased the enzyme activity to $71 \%$ for $A$. niger at $50^{\circ} \mathrm{C}$. Similar results were obtained by (Prakash et al., 2012, Sarkar et al., 2013, Pirota et al., 2013 ,Boonrung etal., 2014, Kaushik et al., 2014, Das and Ray 2016, Abdul Wahab et al., 2016, Ahmed et al., 2016, Boonchuay et al., 2016, Bedade et al., 2017, Ping et al., 2017, and Mehnati-Najafabadi et al., 2018). 
Marwa, H. M., et al.

2.Thermal stability of xylanase production from $A$. niger.

Results recorded in Figure (7) showed that the thermal stability of xylanase enzyme from A.niger was $50^{\circ} \mathrm{C}$ with relative activity $100 \%$ after $10 \mathrm{~min}$, whereas, increasing the time to 20,30, 40, 50 and 60min gradually decreased the enzyme activity to $71 \%$ for $A$. niger at $50^{\circ} \mathrm{C}$. Similar results were
FJARD VOL. 35, NO. 1. PP. 41-56 (2021)

obtained by (Prakash et al., 2012, Sarkar et al., 2013, Pirota et al., 2013 ,Boonrung etal., 2014, Kaushik et al., 2014, Das and Ray 2016, Abdul Wahab et al., 2016, Ahmed et al., 2016, Boonchuay et al., 2016, Bedade et al., 2017, Ping et al., 2017, and Mehnati-Najafabadi et al., 2018).

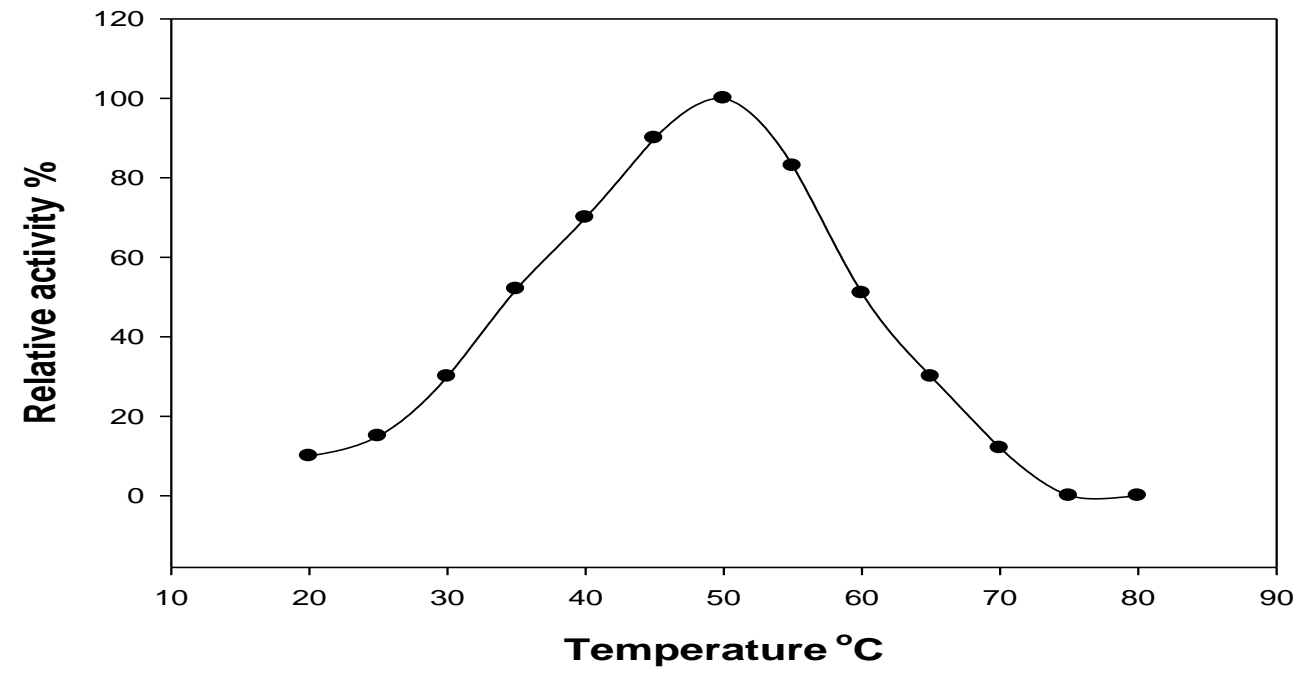

Figure (6) Effect of temperature on the activity of partial purified xylanase from Aspergillus niger.

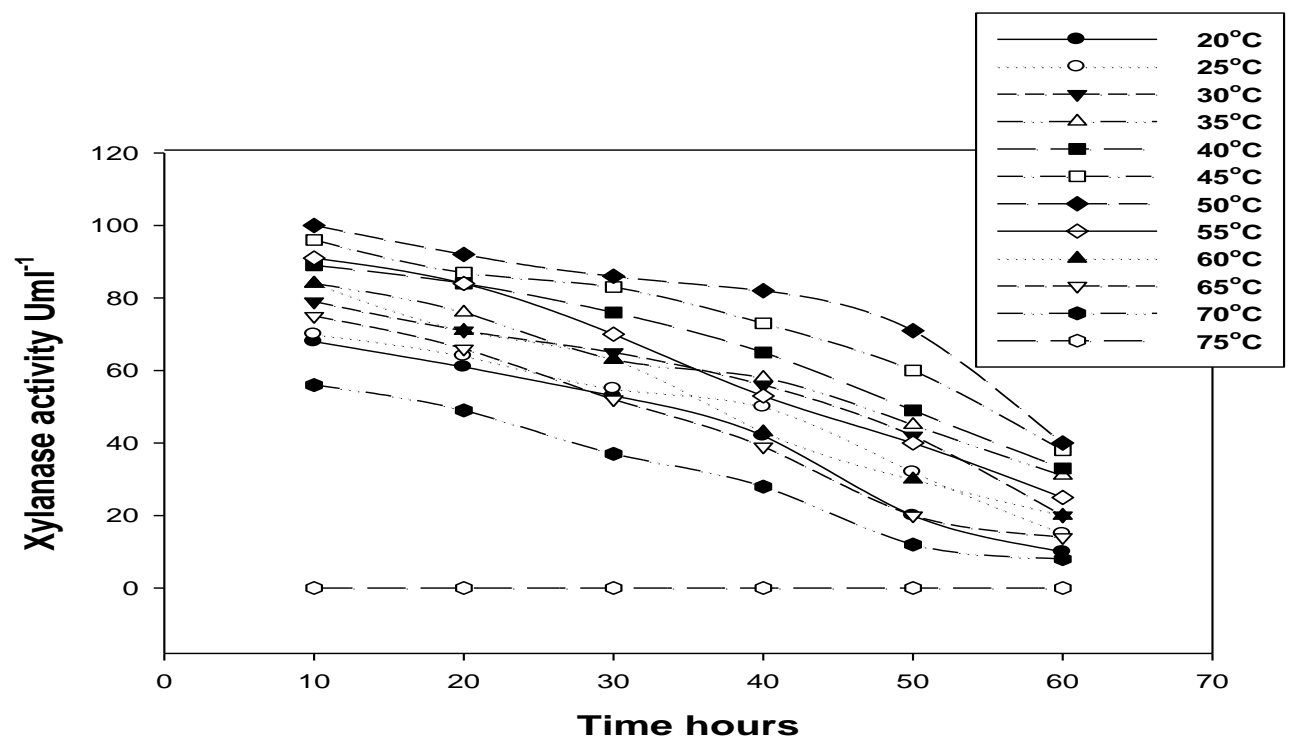


Figure (7) Thermal stability of partial purified xylanase from A. niger.

Effect of metal ions and chemical reagents on xylanase activity from A. niger.

Xylanase was tested in the presence of different metal ions and chemical reagents as show in Table (4). In our study $\mathrm{CaCl}_{2}, \mathrm{NaCl}, \mathrm{MgSO}_{4}$ and EDTA strongly xylanase activity. But, was inhibited by $\mathrm{CoCl}_{2}$. $\mathrm{KCl}, \mathrm{FeSo}_{4}$ and $\mathrm{CuSo}_{4}$ and hydroxyl quinolone. Addition of $\mathrm{K}^{+}$and $\mathrm{Mn}^{2+}$ also caused inhibitory effect on xylanase activity. xylanase was activated by the presence of $\mathrm{CaCl}_{2}, \mathrm{NaCl}, \mathrm{MgSo}_{4}, \mathrm{NaCl}$ and EDTA. Also, in is connection Das and Ray (2016) concluded that $\mathrm{K}^{+}$ and $\mathrm{Cu}^{2+}$ have stimulatory effect on enzyme substrate reaction whereas $\mathrm{Mn}^{2+}, \mathrm{Pb}^{2+}$ and $\mathrm{Ni}^{2+}$ were found to inhibit enzyme activity. Heavy metals like $\mathrm{Hg}^{2+}$ and $\mathrm{Ag}^{+}$have complete inhibitory effect on enzyme substrate reaction even at $1.0 \mathrm{mM}$ concentration. $\mathrm{Hg}^{2+}$ may interact with the sulphite residues present on the enzyme, thus inhibiting the enzyme activity. The other metal ions have variable inhibitory effect on the activity at higher concentration. This could be due to metal catalyzed oxidation reduction of the active sites of enzyme.
Some metal ions and reagents significantly affect xylanase activities. A common trend has been recognized in many cases for enzyme activity negatively affected by heavy metals like $\mathrm{Hg}^{+2}, \mathrm{Fe}^{+2}, \mathrm{Co}^{+2}, \mathrm{Mn}^{+2}, \mathrm{Ag}^{+2}$, $\mathrm{Cu}^{+2}$, and $\mathrm{Pb}^{+2}$ and reagents like urea and EDTA as inhibitors, whereas $\mathrm{Ca}^{+2}$ and $\mathrm{Mg}^{+2}$ have been reported to be enzyme activators (Yinan et al., 2008 and Zhou et al., 2009). Heavy metals like $\mathrm{Ag}^{+2}, \mathrm{Hg}^{+2}$ and reagents like EDTA were shown to inhibit the enzyme activity by $80-90 \%$. Bivalent alkaline elements $\mathrm{Ca}^{+2}$ and $\mathrm{Mg}^{+2}$ enhanced enzyme activity by $10-15 \%$. Surprisingly, EDTA enhanced the activity of endoxylanase from $A$. usamii. It is predicted that $\mathrm{Ca}^{+2}$ and $\mathrm{Mg}^{+2}$ ions help stabilize the enzymesubstrate complex thereby elevating enzyme activity. On the contrary, EDTA is a chelating agent which removes ions from the enzymes thereby inhibiting their activity (Juturu and Wu 2014).

\section{Conclusion}

Partial purification of xylanase enzyme is very important to prepare enzyme to use in applied. 
Marwa, H. M., et al.

FJARD VOL. 35, NO. 1. PP. 41-56 (2021)

Table (4) Effect of metal ions and chemical reagents on xylanase activity from A.niger.

\begin{tabular}{|c|c|c|c|}
\hline Chemical reagents & Final molarity (m M) & \multicolumn{2}{|c|}{ Relative activity \% } \\
\hline None control & --------- & \multicolumn{2}{|c|}{100} \\
\hline \multirow{2}{*}{$\mathbf{C a}^{2+}$} & 1 & 111 & +11 \\
\hline & 5 & 104 & +4 \\
\hline \multirow{2}{*}{$\mathrm{Co}^{2+}$} & 1 & 20 & -80 \\
\hline & 5 & 60 & -40 \\
\hline \multirow{2}{*}{$\mathbf{Z n}^{2+}$} & 1 & 0.0 & -100 \\
\hline & 5 & 0.0 & -100 \\
\hline \multirow{2}{*}{$\mathbf{N a}^{+}$} & 1 & 110 & +10 \\
\hline & 5 & 101 & +1 \\
\hline \multirow{2}{*}{$\mathbf{K}^{+}$} & $\mathbf{1}$ & 90 & -10 \\
\hline & 5 & 85 & -15 \\
\hline \multirow{2}{*}{$\mathrm{Fe}^{2+}$} & 1 & 50 & -50 \\
\hline & 5 & 33 & -67 \\
\hline \multirow{2}{*}{$\mathrm{Cu}^{2+}$} & 1 & 5 & -95 \\
\hline & 5 & 17 & -24 \\
\hline \multirow{2}{*}{ Ag $\mathrm{No3}$} & 1 & 140 & +40 \\
\hline & 5 & 103 & +3 \\
\hline \multirow{2}{*}{$\mathrm{Mn}^{2+}$} & $\mathbf{1}$ & 13 & -87 \\
\hline & 5 & 15 & -85 \\
\hline \multirow{2}{*}{$\mathrm{Mg}^{2+}$} & 1 & 140 & +40 \\
\hline & 5 & 135 & +35 \\
\hline \multirow{2}{*}{$\mathrm{NaN}_{3}$} & 1 & 116 & +16 \\
\hline & 5 & 101 & +1 \\
\hline \multirow{2}{*}{$\mathrm{LiCo3}$} & 1 & 102 & +2 \\
\hline & 5 & 97 & -3 \\
\hline \multirow{2}{*}{ EDAT*** } & 1 & 130 & +30 \\
\hline & 5 & 120 & +20 \\
\hline \multirow{2}{*}{ 8-hydroxy quinoline } & 1 & 90 & -10 \\
\hline & 5 & 85 & -15 \\
\hline
\end{tabular}


Marwa, H. M., et al.

References

Abdul Wahab, M. K. H.; bin, Jonet, bin, M. A.; and Illias, R. M.; (2016). Thermostability enhancement of xylanase Aspergillus fumigatus $R T-1$. Journal of Molecular Catalysis B: Enzymatic, 134, 154-163.

Adsul, M. G.; Ghule, J. E.; Singh, R.; Shaikh, H.; Bastawde, K. B.; Gokhale, D. V., and Varma, A. J. (2004). Polysaccharides from bagasse: Applications in cellulase and xylanase production. Carbohydrate Polymers, 57(1), 67-72.

Ahmed, S. A.; Saleh, S. A. A.; Mostafa, F. A.; Abd El Aty, A. A.; and Ammar, H. A. M.; (2016). Characterization and valuable applications of xylanase from endophytic fungus Aspergillus terreus KP900973 isolated from Corchorus olitorius. Biocatalysis and Agricultural Biotechnology, 7, 134-144. .

Bailey, M.; Biely, P.; and Poutanen, K. (1992). Laboratory testing of methods for assay of xylanase activity. J. Biotechnol. 23, 257270.

Bedade, D.; Berezina, O.; Singhal, R.; Deska, J.; and Shamekh, S. (2017). Extracellular xylanase production from a new xylanase producer Tuber maculatum mycelium under submerged fermentation and its characterization. Biocatalysis and Agricultural Biotechnology, 11(July), 288-293.

Beg, Q. K.; Kapoor, M.; Mahajan, L.; and Hoondal, G. S. (2001). Microbial xylanases and their industrial applications: A review.
FJARD VOL. 35, NO. 1. PP. 41-56 (2021)

Applied Microbiology and Biotechnology, 56(3-4), 326338.

Boonrung, S.; Mongkolthanaruk, W.; Aimi, T.; Boonlue, S.; (2014). Cellulase and xylanase acting at alkaline $\mathrm{pH}$ from mushroom, Leucoagaricus meleagris $\quad K K U-C$. Chia MaiJ.Sci.41(1),84-96.

Boonchuay, P.; Takenaka, S.; Kuntiya, A.; Techapun, C.; Leksawasdi, $\quad$ N.; Seesuriyachan, P.; and Chaiyaso, T.; (2016). Purification, characterization, and molecular cloning of the xylanase from Streptomyces thermo vulgaris TISTR1948 and its application to xylooligo saccharide production. Journal of Molecular Catalysis B: Enzymatic, 129, 61-68.

Chapla, D.; Pandit, P.; and Shah, A. (2012). Production of xylooligo saccharides from corncob xylan by fungal xylanase and their utilization by probiotics. Bioresource Technology, 115, 215-221.

Das, A., and Ray, L. (2016). Production of crude xylanase using an isolated fungal strain Aspergillus sp. S6 by solid state fermentation. Materials Today: Proceedings, 3(10), 3343-3360.

Englard, S.; and Seifter, S. (1990). Precipitation techniques. Methods Enzymol. 182, 285300.

Gilbert, H.J. and Hazlewood, G.P. (1993). Bacterial cellulases and xylanases, J. Gen. Microbiol. 139 187-194.p29

Haltrich, D.; Nidetzky, B.; Kulbe, K. D.; Steiner, W., and Župančič, S.; (1996). Production of fungal 
Marwa, H. M., et al.

xylanases.

Bioresource

Technology, 58(2), 137-161.

Juturu, V., and Wu, J. C. (2012). Microbial xylanases: Engineering, production and industrial applications. Biotechnology Advances, 30(6), 1219-1227.

Juturu, V.; and Wu, JC.; (2014). Microbial exo-xylanases: a mini review. Appl Biochem Biotechnol 174:81-92.

Katapodis, P.; Kavarnou, A.; Kintzios, S.; Pistola, E.; and Kekos, D.; (2000). Christakopoulos Production of acidic xylooligosaccharides by a family 10 endoxylanase from Thermoascus aurantiacus and use as plant growth regulators. Biotechnol Lett; 24:1413.

Katapodis, P.; Kavarnou, A.; Kintzios, S.; Pistola, E.; and Kekos,

D.

(2002).

Christakopoulos Production of acidic xylooligosaccharides by a family 10 endoxylanase from Thermoascus aurantiacus and use as plant growth regulators. Biotechnol Lett. 24: 1413.

Kaushik, P.; Mishra, A.; and Malik, A. (2014). Dual application of agricultural residues for xylanase production and dye removal through solid state fermentation. International Biodeterioration and Biodegradation, 96, 1-8.

Khanna,S.; and Gauri, (1993). Regulation, purification, and properties of xylanase from Cellulomanas fimi. Enzyme and Microbial Technology 15,990995 .

Lowry, O.H.; Rosebrough, N.J.; Farr, A.L. and Randall, R.J. (1951). Protein measurement
FJARD VOL. 35, NO. 1. PP. 41-56 (2021) with the folin phenol reagent. J. of food Sci., 45:601-604.

Maheshwari, R.; Bjardwai, G. and Bhat, M.K. (2000). Thermophylic fungi: their physiology and enzymes, Microbiol. Mol. Biol. Rev. 64 461-488p29.

Mehnati-Najafabadi, V.; TaheriKafrani, A.; and Bordbar, A. K. (2018). Xylanase immobilization on modified superparamagnetic graphene oxide nanocomposite: Effect of PEGylation on activity and stability. International Journal of Biological Macromolecules, 107(PartA), 418-425.

Mill, P.J. and Tuttobello, R. (1961). The Pectic Enzymes of Aspergillus niger.

Endopolyaalacturonase. Bioch. J. 79:57-64.

Okafor, U. A.; Okochi, V. I.; Onyegeme-okerenta, B. M.; and Nwodo-Chinedu, S. (2007). Xylanase production by Aspergillus niger ANL 301 using agro - Wastes. African Journal of Biotechnology, 6(14), 17101714.

Pirota, R. D. P. B.; Tonelotto, M.; Delabona, P. da S.; Fonseca, R. F.; Paixão, D. A. A.; Baleeiro, F. C. F.; Bertucci Neto, V., and Farinas, C. S. (2013). Enhancing xylanases production by a new Amazon Forest strain of Aspergillus oryzae using solid-state fermentation under controlled operation conditions. Industrial Crops and Products, 45, 465-471.

Ping, L.; Chen, X.; Yuan, X.; Zhang, M.; Chai, Y.; and Shan, S.; (2017). Application and comparison in biosynthesis and 
Marwa, H. M., et al.

bio degradation by Fusarium solani and Aspergillus fumigatus cutinases, Int. J.Biol. Macromol. 104: 1238-1245.

Prakash, B.; Vidyasagar, M.; Jayalakshmi, S. K., and Sreeramulu, K. (2012). Purification and some properties of low-molecular-weight extreme halophilic xylanase from Chromohalobacter sp. TPSV 101. Journal of Molecular Catalysis B: Enzymatic, 74(3-4), 192-198.

Puchart, V.; Katapodis, P.; Biely, P.; Kremnický, L.; Christakopoulos, P.; Vršanská, M.; Kekos, D.; MacRis, B. J.; and Bhat, M. K. (1999). Production of xylanases, mannanases, and pectinases by the thermophilic fungus Thermomyces lanuginosus. Enzyme and Microbial Technology, 24(5-6), 355-361.

Sarkar, D.; Laha, S.; and Chaki, S. (2013). Isolation, purification and characterization of xylanase, produced by a new soil born Bacillus sp. International Journal of Pharma and Bio Sciences, 4(4), 571-576.

Seyis, I., and Aksoz, N., (2003). Determination of some physiological factors affecting xylanase production from Trichoderma harzianum 1073 D3. Microbiologica 26,75-81.

Simair, A.A.; Dahot, M.U.; and Mangrio, S.M., (2010). Production of xylanase enzyme by Pleurotus eryngii and Flamulina velutipes grown on different carbon sources under submerged fermentation. World
FJARD VOL. 35, NO. 1. PP. 41-56 (2021)

Appl. Sci. J. (Spec. Issue Biotechnol. Genet. Eng.) 8, 4749.

Singh, S., (2003). Thermomyces lanuginosus: properties of strains and their hemicellulases. FEMS Microbiol. Rev. 27, 3-16.

Somogyi, M. (1952). Notes on sugar determination. J. Biol. Chem., 195, 19-23.

Thomas, L.; Sindhu, R.; Binod, P., and Pandey, A. (2015). Production of an alkaline xylanase from recombinant Kluyveromyces lactis (KY1) by submerged fermentation and its application in bio-bleaching. Biochemical Engineering Journal, 102, 24-30.

Walia, A.; Guleria, S.; Mehta, P.; Chauhan, A.; and Parkash, J. (2017). Microbial xylanases and their industrial application in pulp and paper biobleaching: a review. 3 Biotech, 7(1), 1-12.

Whistler, R. L. and Richards, E. L. (1970). Hemicelluloses. In: The Carbohydrates. pp. 447-469. Vol. 2a. Pigman, W. and Horton, D., Eds., Academic Press, New York.

Yinan ,Y. K. S.; Lifeng, P.; Jingmei, L.; (2008). Cloning, sequencing and expression of a novel xylanase cDNA from a newly isolated Aspergillus awamori in Pichia pastoris. Afr J Biotechnol; 7:4251-9.

Zhou, C.; Yongtao, W.; Minchen, W. W. W.; and Dongfeng, $L$. (2009). Heterologous expression of xylanase II from Aspergillus usamii in Pichia. pastoris. Food Technol. Biotechnol.; 1:90-5. 
Marwa, H. M., et al.

FJARD VOL. 35, NO. 1. PP. 41-56 (2021)

$$
\text { الملخص العربي }
$$

\section{تنقية انزيم الزيلانيز الفطري وبعض خصائصه}

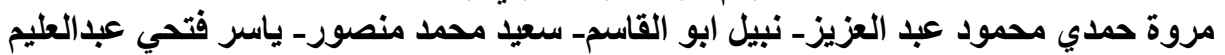

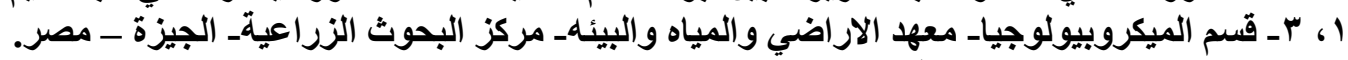

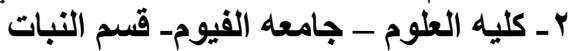

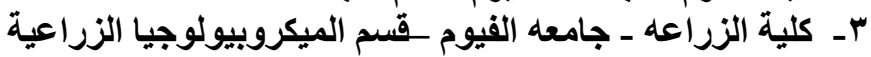

في هذه الدر اسه تم انتاج انزيم الزيلانيز من سلالة الاسبرجيلس نيجر ، باستخدام مطحون اكواز الذرة اساسي التئي

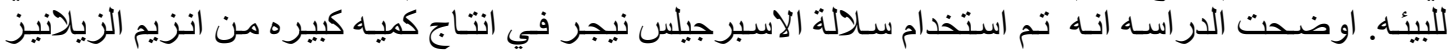

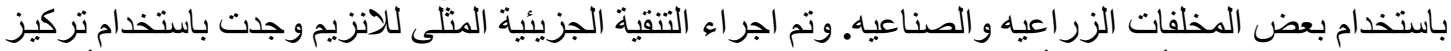

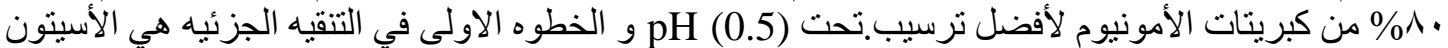

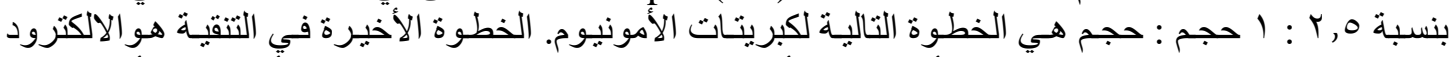

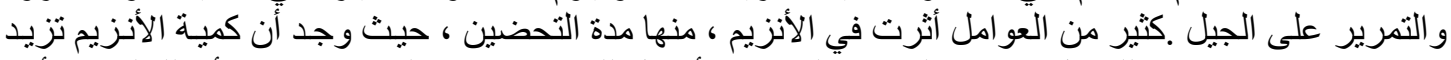

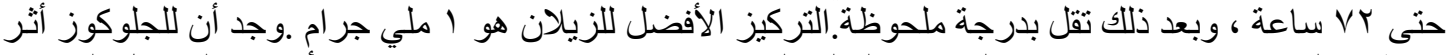

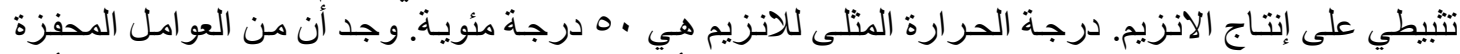

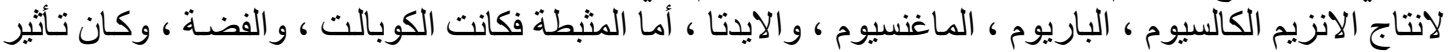

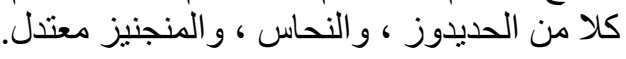

